Article

\title{
Mural Art Conservation Data Recording (SCIMA): The Graart Project
}

\author{
Laura Rivaroli ${ }^{1,2, *(1)}$, Paola Moretti ${ }^{2}$, Antonio Caricchio ${ }^{2}$ and Andrea Macchia ${ }^{2}$ \\ 1 Department of Architecture, Univesity of Bologna, 40126 Bologna, Italy \\ 2 YOCOCU APS, YOuth in COnservation of CUltural Heritage, 00185 Roma, Italy; \\ paolamoretti84@gmail.com (P.M.); antonio.caricchio@gmail.com (A.C.); andrea-macchia@tiscali.it (A.M.) \\ * Correspondence: laura.rivaroli2@unibo.it; Tel.:+39-388-1120-583
}

Citation: Rivaroli, L.; Moretti, P.;

Caricchio, A.; Macchia, A. Mural Art Conservation Data Recording (SCIMA): The Graart Project. Heritage 2021, 4, 4222-4232. https://doi.org/ $10.3390 /$ heritage 4040232

Academic Editors: Nicola Masini and Fernanda Prestileo

Received: 31 August 2021

Accepted: 30 October 2021

Published: 4 November 2021

Publisher's Note: MDPI stays neutral with regard to jurisdictional claims in published maps and institutional affiliations.

Copyright: (c) 2021 by the authors. Licensee MDPI, Basel, Switzerland. This article is an open access article distributed under the terms and conditions of the Creative Commons Attribution (CC BY) license (https:/ / creativecommons.org/licenses/by/ $4.0 /)$.

\begin{abstract}
Urban art in Italy is experiencing a remarkable evolution that has quickly modified urban spaces, especially in suburban areas. More and more often, we are witnessing the birth of works of art that have been commissioned by festivals, or institutional projects next to spontaneous street artworks. These large projects, often defined as "urban renewal", when carried out through a wellthought-out design, can become real open-air museums. The proliferation of these creative and legal projects has raised the question of whether street art should be preserved over time. The conservation, or even restoration, of urban art has recently become a controversial topic in scientific debate. In Italy, different associations of researchers are developing new methodologies for preserving street artworks; everyone agrees on the importance of the implementation of good conservation practices. The documentation of the existing condition of a work of art is the first step to start taking care of it. In this article we introduce SCIMA (Scheda Conservativa Informatizzata Mural Art), a digitizing conservation data report that is specific for mural art. The aim of SCIMA was to define the existing condition of the work of art, starting with the socio-cultural and artistic importance, to describe its environment, to define the materials used and its deterioration problems, to suggest conservative interventions. It was born as an analogical tool (sheet) but we are working on digitizing it (database) in order to maintain access to the data recorded for the future.
\end{abstract}

Keywords: mural art; preventive conservation; cultural heritage; dissemination; scientific glossary; documentation

\section{Introduction}

The YOUR ART project [1], born from the collaboration between YOCOCU APS and M.U. Ro, has conducted a study on urban artworks and public art that was carried out by compiling a computerized data file about the main "biographical" details of artworks. These details included various information: the location, techniques and materials used by the artist, and data that allowed the recording and monitoring of the condition of the artwork. The term "condition" refers to the state of the preservation of the artifact. The analysis of the physical appearance, the chemical properties of materials and the degradation of products is essential for decision-making considering a future conservation intervention [2]. These elements define the Mural Art Conservation Data Recording (SCIMA).

The Italian art legal system sets a difference between generic artworks and artworks of cultural interest under the Cultural Heritage Law. Artworks with specific characteristics receive recognition for their inherent cultural value and are subject to special rules. In 2017, the Cultural Heritage Law was subject to important reforms concerning the time threshold beyond which an item can be deemed culturally important; this was changed from 50 to 70 years after an artwork's creation, by a non-living artist. This means that recent urban art is left out of the Italian legal protection of Cultural Heritage. Luckily, in Italy, several urban art projects have been designed and carried out with the idea of permanence of the artworks, through a careful choice of materials and methods with the aim of ensuring the 
durability of their authenticity [3,4]. The creation process itself determines the endurance of the work; for this reason, the choice of location and wall, as well as the quality of paints and other materials, is fundamental [5]. The base of this strategy is the collaboration among curators, artists, and professionals in conservation of cultural heritage, citizenship, public administrations, and private entities. This partnership can carry out long-term projects which enable maintenance of artworks in the urban context not only as an artistic object, but also as a reference point for the community. These artworks are born already with a social desire for conservation, in a space outside of the controlled environment of the "Classic" museum. This aspect represents a big challenge for the above-mentioned partnership: the need to preserve urban artworks [6-10]. One of the first steps in this direction was the development of a specific code of work ethics; conservation and restoration professionals have tacitly adopted the one proposed by E.C.C.O. or the Ge-IIC code of ethics for the performance of their work [Grupo de arte urbano (2016)-Marcal].

While many cities are aware that large urban murals change, and improve their physiognomy, some of them are just beginning to understand the problems posed by their conservation: the ephemeral existence of some artworks, vandalic anthropic actions, or a lack of choice in the materials used. For example, in 2015, Vigo City Council joined this trend with the aim of transforming an urban festival into an open-air museum within Vigo, Ciudad de color [11]. Among the projects YOCOCU is working on, GRAArt is an Urban Contemporary Art project that traces the history and mythology of Rome through works of street art. GRAArt highlights the cultural and artistic fortune of the Eternal City and evokes those stories in which Rome has been a protagonist over the centuries, with the aim of healing the cultural rift that exists between the capital's monumental historical center and its outskirts. Painted in the peripheries of Rome, the murals of GRAArt are in fact inextricably linked to the often little-considered or even the forgotten myths, legends and anecdotes which deal with the memories and identity of those specific areas of the city, of which these contemporary paintings are intended to become a symbol. Thanks to the GRAArt project, which was commissioned by the Brand and Image Office, designed by David Diavù Vecchiato and realized by the staff of M.U.Ro, ANAS- the Italian motorways and highways corporation-motorists leaving its Grande Raccordo Anulare-the busiest motorway in Italy-are now welcomed with wonderful large-scale works of art that powerfully communicate the message, Welcome to Rome. The project currently consists of 17 pieces created by artists from all over the world. It is a virtuous example of collaboration and a sharing of knowledge among artists, but also a collects different supports, paint products and artistic techniques (Figure 1).
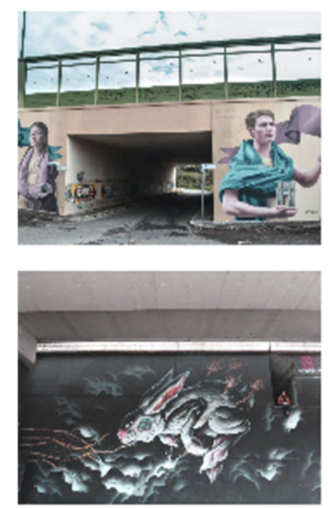
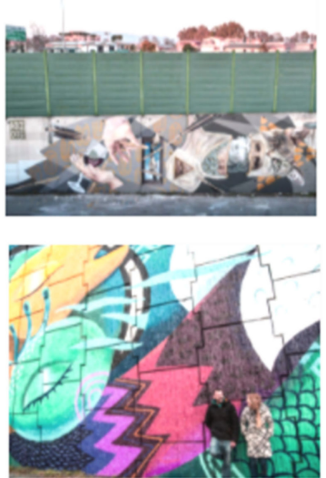
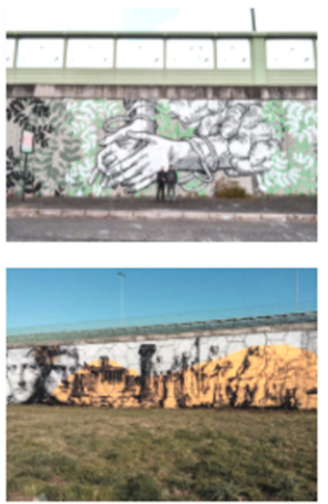
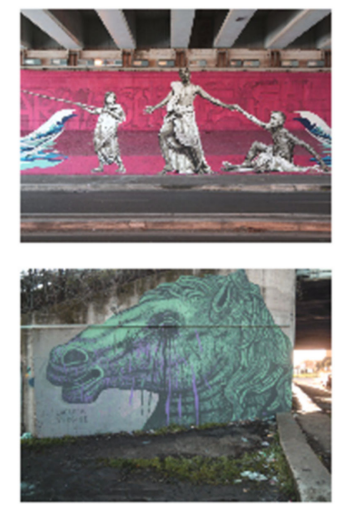

Figure 1. Selection of a part of GRAArt murals.

The GRAArt project [12] has been given the opportunity for a direct and prolonged observation of the urban artworks from the design phase to their realization, including their preservation aspects. The team of professionals believed it to be a rare opportunity to collaborate in a team, shared their needs and knowledge, and discussed urban art conservation. Thanks to this experience they understood the importance of having a standardized 
lexicon to speak commonly on mural artworks. The first need that emerged was to realize a system that records the materials used by the artists, the cultural and social data, and the conservation state of artworks. The General Catalogue for the Cultural Heritage used by ICCD [13], with 30 types of cataloguing sheets, is focused on the collection of documentation and scientific information on the artworks and is missing a specific lexicon for urban art and the necessary data for preservation and protection interventions [14-16]. The problem is that, in Italy, there are no a unique types of conservation data records for the various cultural heritage fields. Although there are guidelines which come directly from the Ministry of Cultural Heritage, the important institutes for conservation and restoration (ICR, OPD), as well as the major museums and art galleries have their own types. In regard to urban and street art, the two reference data records, which are useful but not specific, are the conservation mural painting data records (ICR-OPD) and the contemporary art data records (OAC-Opera d'Arte Contemporanea) from ICCD. To meet the urban art cataloguing needs, YOCOCU APS, in collaboration with M.U. Ro, carried out SCIMA (acronym for: Scheda conservativa informatizzata mural art), an innovative and efficient data recording system. SCIMA consists of a digital sheet, which is capable of recording the artistic, historical, anthropological, and environmental value of an artwork through a conservative sheet. This challenge is even more difficult if, in addition to the difficulty of managing data that comes from different professional skills, we add the need to use, and therefore to define, a standard vocabulary that is accepted by all professionals involved in urban art. This documentary activity should always be preceded by the indexing and classification of specific information. The technical lexicon constitutes the starting point for the design of a data system, digital or otherwise, such that graphic conventions would be the formal result of the classification of the phenomena of degradation, along with a description of execution techniques and the range of historical or current interventions.

Recently, in order to document the huge number of murals and graffiti present in the territory, several projects were born. In Italy, the Google Arts \& Culture and Inward, the national observatory on urban creativity and a partner of the Google Cultural Institute since 2017, have collected images and data about artists for more 350 artworks [17]. In Rome, a special office of the Sovrintendenza Capitolina, the body for the conservation of municipal cultural heritage, opened a special office for urban art. The street art recognitions realized by the City of Melbourne and the City of Adelaide represent an interesting experience for visitors, with geo-referencing information which is useful to explore both the city and the role of urban art for the community. The aim of these projects is creating a large online "collection", able to collect and catalog the street-art works present in the cities. Often, these collections have been images, tour information, walking tours, and descriptions of the artists, that have missed a systematic data recording design and the recording of data useful for the urban art's preservation [18]. The cataloging of mural artworks must represent the operational exemplification of the concept of conservation. The collected data have become the key tools for the knowledge, protection, and dissemination of artistic heritage, by putting aside for a moment the problems of enhancement, which must, in any case, be related to those of conservation. Some authors have already reflected on the need to preserve urban art, such as Mata Delgado [19], Ciancabilla [20], Cadetti [21], Luque Rodrigo [22], and Chatzidakis [23], who place the origin of this interest in the UK, by indicating society as the trigger that has created specific working groups, such as the Ge-IIC Urban Art Working Group. The project of YOCOCU APS, for the realization of a Conservative computerized Survey for Mural Art (SCIMA), has been the result of professionals sharing among other professionals involved in this field-from the artist to the curator, from the conservation scientist to the restorer. This project has the ambition not only to "photograph" the urban art and determine its role in the community, but also to plan data-driven, conservative interventions, which is based the conservation state of the artworks. The created data recording sheet was tested in the field (or better to say in the streets) on the works of the project M.U. Ro and GRAArt. Case studies helped in the refining of definitions and the systematization of information. Once the parameters 
of collection have been defined, a common mode to organize the whole information in the texts, and subsequently in a graphic and photographic system, is required to facilitate data cataloguing.

\section{Materials and Methods}

The importance of drawing up specific data recording (sheet) for different types of works in the field of cultural heritage has already long been declared in the world of restoration [24-30]. In contemporary art, such as in muralism, the variety of materials and of execution techniques makes sheet planning difficult. On this basis, the goal was to design a tool that documents the conservation status of the works of art in a detailed and standardized way, to catalogue different and complex situations in a common and clear language. In doing so, it would be possible to schedule consciously programmed maintenance, and to plot a preventive conservation program for each opera. The proposed model was to expand the field of cultural heritage through a closed-ended file type which was specific to the works of mural art, that allowed a correct comparison of the data entered. The model developed for the works of mural art was based primarily on the assessment of the state of conservation of the asset, and the analysis of the conservative context in which it was located. Data recording, description, and an analysis of conservation status (as a whole of the conditions of the constituent materials at a precise moment in time) is a preliminary action to any conservation and/or restoration work. The verification of the "health" conditions of the works of art has been monitored through the drafting of conservative files, which were merged into a usable and implementable database following any modification to the conditions of conservation of the paintings. The main steps of the work are defined as follows:

- Development of a computerized Conservation Survey for Mural Art (SCIMA) with the elaboration of a specially designed path;

- Definition of a specific and shared lexicon;

- Definition of a specific lexicon explained through photographic documentation;

- Systematic detection of the "health" conditions of the works through the drafting of conservation recording that will analyze all the different components: pictorial layers, supports, environmental;

- Making of a photographic campaign with shots related to the work and significant details;

- Programming of a maintenance plan for the works;

- Planning approach in order to put preventative conservation into practice.

This constituted an essential instrument for the implementation of a plan for the effective monitoring of the state of works, but was considered also suitable for management purposes, as well as for the realization of in-depth studies on painting techniques and their conservation problems. Moreover, a planning approach is one of the best, and with no doubt a more effective, tool of preventive conservation. Preventive conservation can be defined as any measure that prevents damage or reduces the potential for it. It focuses on collections rather than individual objects, nontreatment rather than treatment, and both indoor and outdoor environments. The preliminary step to plan an effective conservation intervention was to study and to analyze a work of art and its conservation status. With comprehensive, preventive conservation, the need for individual treatment can, over time, be reduced to more manageable levels, putting personnel and financial resources to more effective use. To guarantee a detailed analysis of the work and a common vocabulary, a technical sheet which was characterized by closed sections was created. SCIMA describes the work and the context, facilitating an objective conservation and maintenance plan, as well as a preventive plot. Starting from a descriptive part of the work, in which the execution techniques and the materials used by the artist are reported in depth, with a significant framework of the conservation environment. The sheet continues with the documentation of the conservation condition (the types of degradation and deterioration products) and with a section devoted to conservation proposals (safety 
measures, restoration, maintenance, etc). SCIMA ends with a list of specific, related documents (bibliographic, archive, graphic, scientific documentation, etc.) (Figure 2).

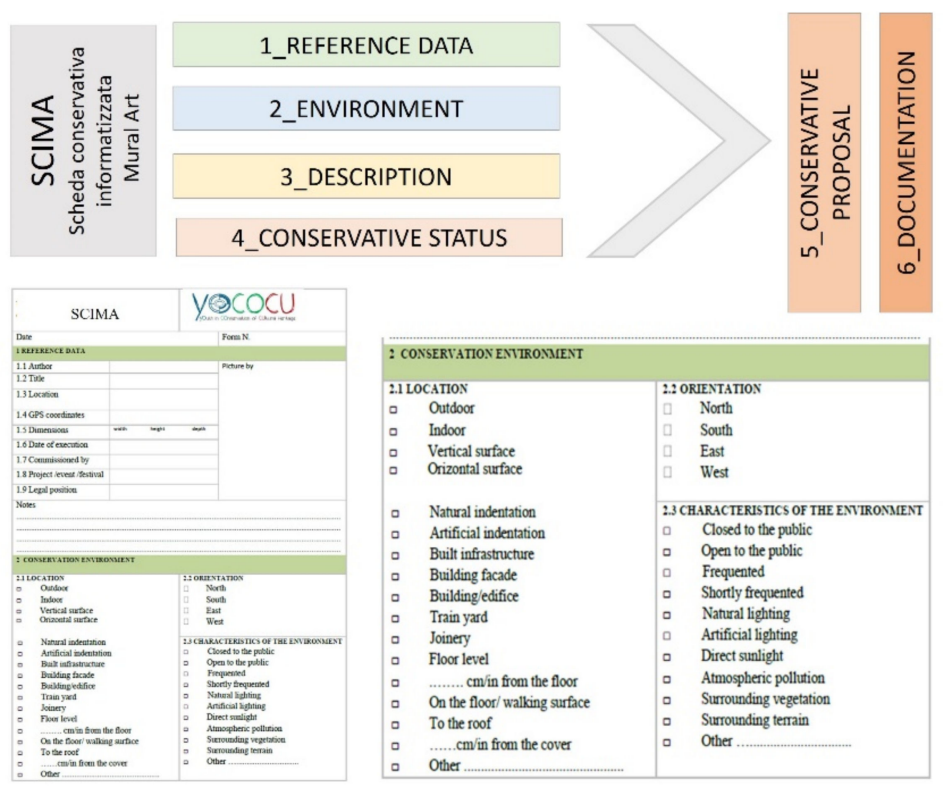

Figure 2. SCIMA digitizing conservation data report specific for mural art.

SCIMA is composed of six sections, each divided into chapters which are, in turn, composed of paragraphs and a variable number of items. To ensure consistency, the entries have already been inserted, and contain lists of terms to choose in order to obtain a comparable compilation even if they performed by different individuals. At the end of each section there is a blank field in which open-ended notes may be added. The 6 sections are divided into the sequence:
1. REFERENCE DATA
2. ENVIRONMENT
3. DESCRIPTION
4. CONSERVATION STATUS
5. CONSERVATIVE PROPOSAL
6. DOCUMENTATION

1. REFERENCE DATA: the first part is divided into 9 subsections. These subsections introduce the work of art at a general level, by recording the data identifying the artwork, the author, the title, and the location, through the GPS coordinates that enable the quick finding of the site. In addition, information is requested on the size of the work and for which project, event, or festival the work was created, on whom were the costumers of the project, and on whom are the legal position/proprieties of the artwork. At the end of the section, it is possible to write any extra information in a blank field, and to add a general photo in order to identify the mural.

2. ENVIRONMENT: the second section is dedicated to the ENVIRONMENT in which the work is located. It is divided into 4 subsections composed of pre-filled fields with the possibility of identifying them with crosses, plus a notes section characterized by an open space, to improve data. The place and the surrounding environment are extensively described, highlighting the functional features that allow for the conservation of the work of art. The location, orientation, characteristics of the environment and the type of protection are the four sections which allow one to explore the most relevant aspects of the conservation world in depth. For example, the characteristics of the space are relevant to the understanding of the environment: if the space around the artwork is closed or open to the public; if it is frequented or not; if it is in direct contact to the sunlight or to artificial lighting. These are important aspects which can help to understand the causes 
of degradation phenomena. With this information, we can identify and understand the risk for the artwork. Moreover, as urban features have constantly changed and developed with the increase of the population, the murals, as an integral part of urban areas, have done the same. In fact, the protection and sustainable development of the murals as a source of identity, and the link between the actuality and future play a fundamental role in maintaining urban artworks. The study of the environment on a large scale is important, because it is possible to put the attention on the aspects. Most importantly, based on a static analysis of the State of Conservation (SOC) reports prepared by UNESCO [31] "between 1979 and 2013, 66\% of the damaged properties reported were cultural properties" [32].

3. DESCRIPTION: the third part, composed of 9 subsections, gives a more detailed description of a work of art in terms of its type or typology, style, execution technique and tools used by the artist. This is a considerable number of possibilities to choose in order to enable us to define the work in a better way. This part is especially specific in order to promote the use of a unique technical terminology that different professionals can understand and share.

This section goes on with an overview of the types of materials used in the several layers of the artwork, starting from the pictorial layer that obtains the support and ground layers of the work. In this part, whoever fills out the sheet starts with the external aspect to describe the work. A list of terminologies helps to better define the type of work (mural, top to bottom, stairway, installation etc..) (Figure 3a) and the style used by the artist (3D style, puppet, bubble style, Calligraffiti, etc.) (Figure 3b).
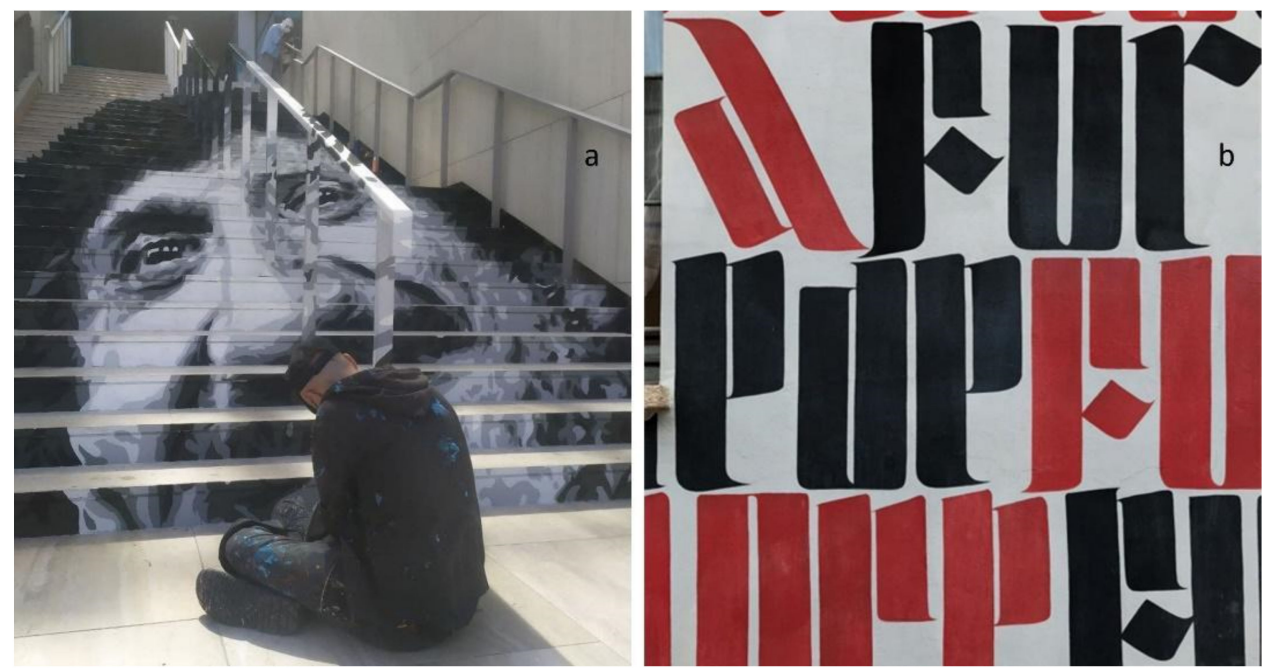

Figure 3. (a) Stairway by Diavù, Rome (IT). (b) Calligraffiti by Ivan Tresoldi, Milan (IT).

In the other subsections, the subsequent lists regard the technical aspects of execution techniques and tools (paint brush, spray, sponge, mop, marker, etc.), or, for example, a list of natural or synthetic paints, to better define the product used.

Those responsible for the sheet have the possibility to add the type of product (commercial name) and the color code (RAL code). This information, which is very often missing in the descriptions of works of mural art, is very important, not only for conservation purposes and restoration projects, but also for the understanding of the degradation of the paints used. It is obvious that the compilation of SCIMA requires a close collaboration both with the artists and the curators of the project. In this subsection, it is possible to define the supports and the ground; this is whether the artwork was made on natural or artificial stone material, or plasters, wood, plastics, or other materials. Particular attention is given to the surface characteristics (smoothed, rough, fine finished, irregular surface), to the type of flooring (asphalt, concrete pavement, epoxy coating etc.), to the surface finish to explain the aspects of the surface (glossy aspect, matte look, presence of transparent coating) and to the presence of signatures, symbols, or tags (Figure 4). 

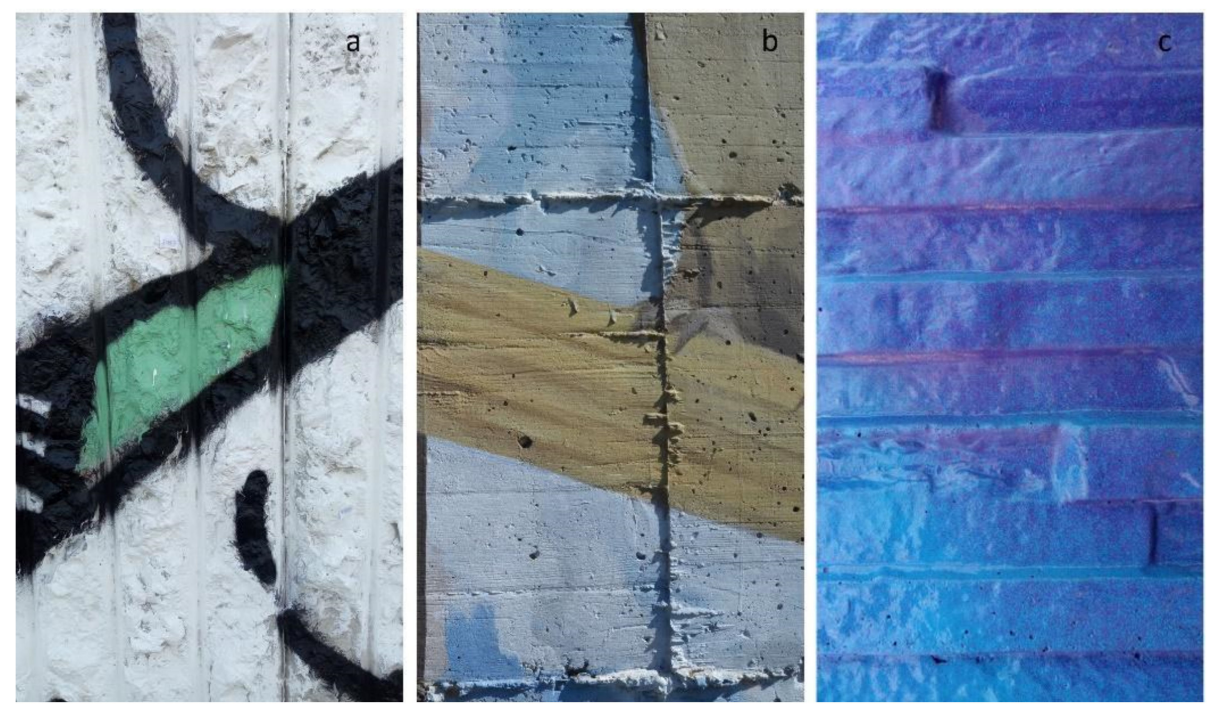

Figure 4. Surface characteristic (a) rough, (b) irregular surface, (c) glossy aspect.

4. CONSERVATION STATUS: the fourth section is divided into 9 subsections and concerns the possible types of degradation that affect both the support and the pictorial layers. The first paragraph describes the general condition of the work, the method of inspection, the general conservation status and an evaluation of the stability grade. A large list of deterioration phenomena is mentioned in order to establish the correct diagnosis that can be attributed to the work of art. The degradation lexicon is divided in order to define damage to the support layer (detachment and loss of material, salt crystallization etc.) and to the paint layer (hairline crack, flakes, abrasion, losses, subflorescence etc.) [33-36]. The separation of these terminologies is necessary to have a precise lexicon to use in mural art conservation. Many degradation phenomena are connected, and are sometimes caused by problems in the support that interfere with the conservative condition of the pictorial layer (Figure 5). Often, the compiler found an anthropically induced deterioration made on the surface, which comprised two different aspects. On one hand, people want to damage artworks because they dislike the artist, the artwork or the project (Figure 6a). On the other hand, people damage the operas because they do not know the importance of the work and therefore do not pay attention to them $[37,38]$. Often, these types of damages are carried out by administrative technicians who sometimes carry out the maintenance of systems without paying attention to the work of art (Figure 6b). An important space is for the analysis of [39].
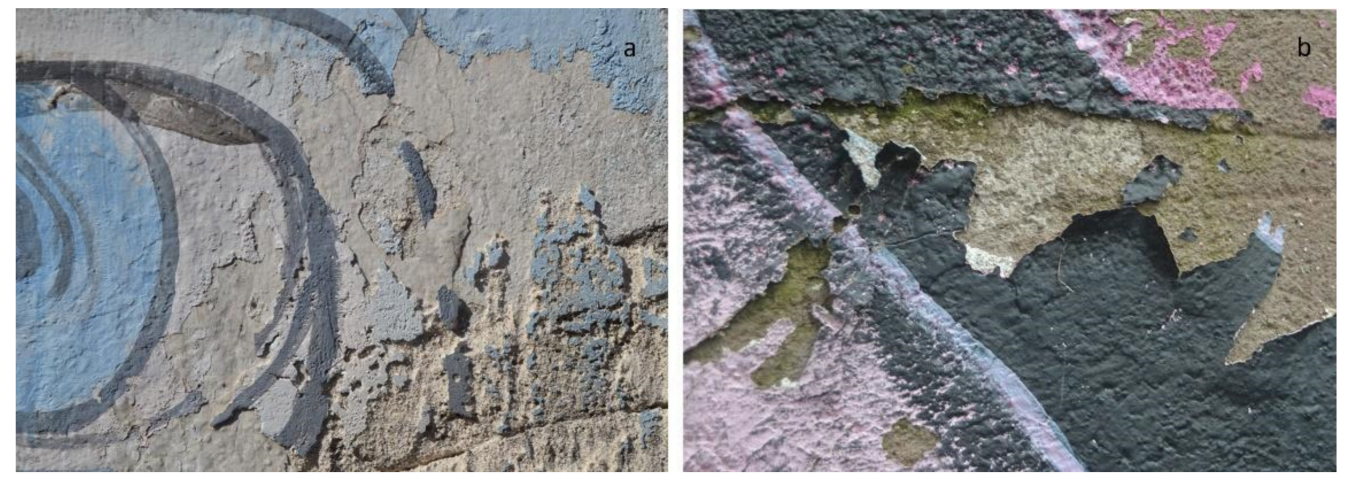

Figure 5. Degradation (dislike of the artist) (a) erosion, fracture, cracks, loss of material, (b) exfoliation.

5. CONSERVATIVE PROPOSAL: the fifth section is divided in two sub sections: the type of intervention and the plan of intervention. This section regards the conservative proposals that would be the outcome/results of the analysis of the previously collected 
data, along with the existing bibliographic and scientific documentation. Any proposal must always be discussed by various professionals (art restorer, conservation scientist, curator, etc) to evaluate a suitable conservative plan that respects the original intentions of the work of art. In addition, in dealing with contemporary art, and therefore most of the time with living artists, it becomes essential to get the artist's opinion. Therefore, the conservative proposals could provide anything from a simple monitoring campaign to an extensive restoration intervention. The methods of the conservation, monitoring and restoration of mural works are not yet codified [40-43]. However, there are many projects that have already been carried out, and publications that have allowed the sharing of applied methodologies [44-46].
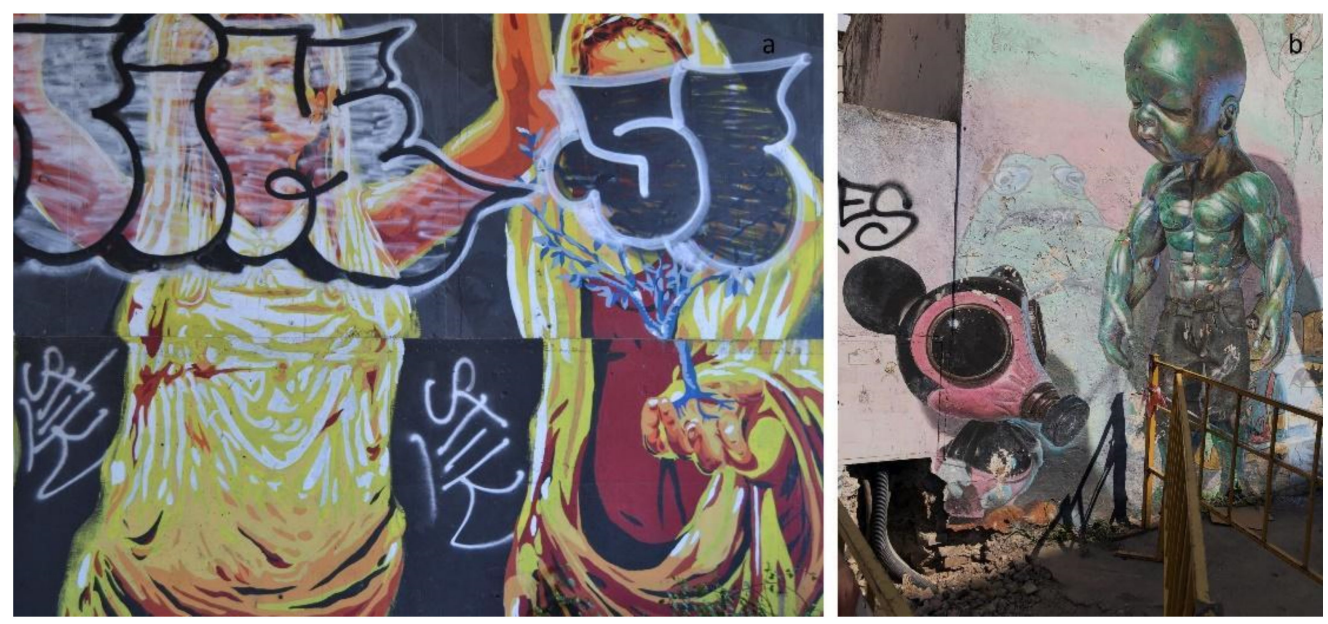

Figure 6. Anthropically induced deterioration (a) vandalism with spray and marker, (b) administrative works.

6. DOCUMENTATION: the sixth and last part concerns all the existing related documents, such as bibliographic documentation, archive documentation and previous intervention documentation, and those documents which are made in tandem with SCIMA, such as photo documentation, graphic documentation, the artist interview, and any scientific investigation. The importance of referencing the other documents is fundamental to unite the information and group all the notions concerning the work [47]

\section{Results}

SCIMA, therefore, may appear articulated, but each part is simultaneously independent as well as connected to the others. It is organized in such a way that allows the sheet to be filled wholly or partially, depending on the compiler, and to still obtain the necessary information. SCIMA aims to be a useful and easy tool for the recognition of the executive techniques and the materials used, as well as the characterization of the state of conservation for works of urban art and public art. The compilation took place in the place of conservation of the works and in close correlation with the curator of the project and with the executors of the work (Figure 7).

This means that, when compared to the other types of data sheets related to ancient artifacts, SCIMA allows the recording of a series of data that are already connected with the process of making the artwork and allows the monitoring of the work conservation condition across its lifetime. This factor has great importance in terms of conservation, by clarifying the materials and execution techniques used and in helping one to understand the deterioration process. All this facilitates the ability to determine a correct conservative approach and to formulate a preventive conservation plan that involves various professionals. The compilation is quick and easy, but requires the presence of a restorer who is specialized in mural paintings, and who knows the techniques and styles that are used for the realization of the works of urban art. Some doubts or uncertainties can be 
solved through the collaboration of artists and curators. The data recorded on the works of the GRAArt project provide the basis for the study of the degradation of surfaces and allow for the proposal of a differentiated maintenance project which is based on the actual conservation conditions found in each work.
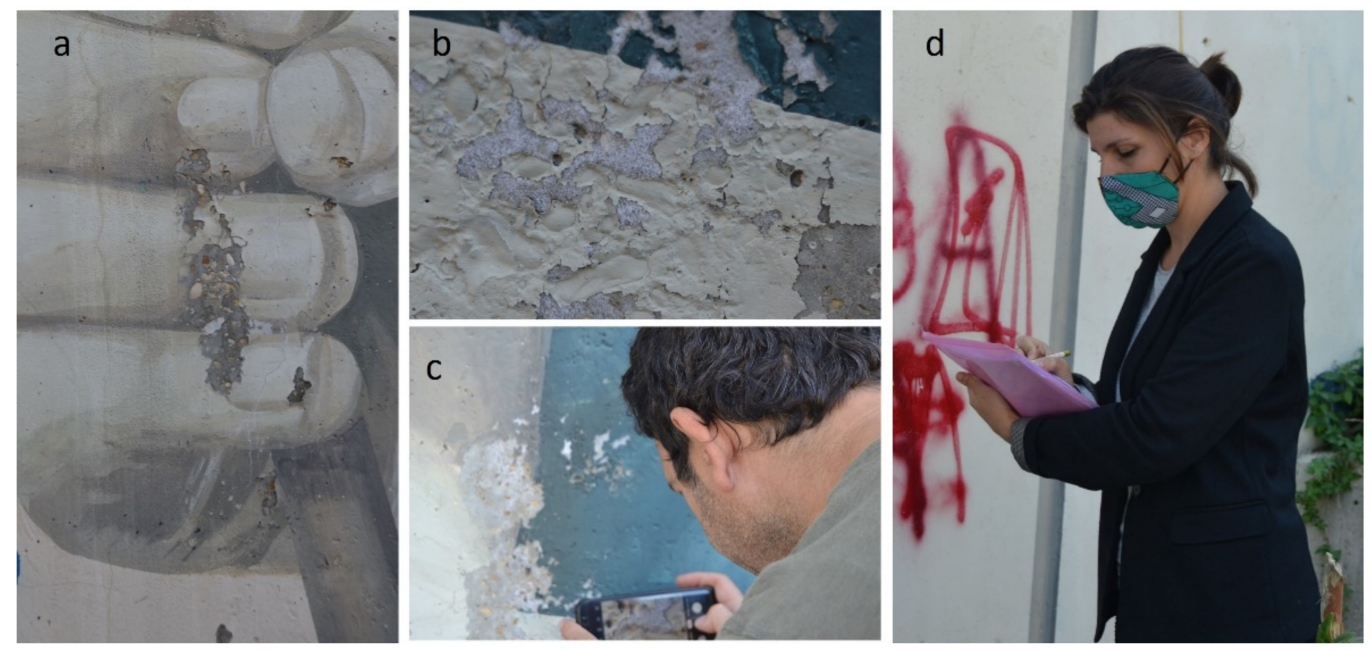

Figure 7. SCIMA compilation in front of Colectivo Licuado made to GRAArt. (a) loss painting layer (b) salt efflorescence (c) photographic documentation (d) SCIMA compilation.

The annual review of the conservation sheets also makes it possible to verify the deviation of the conservation conditions when compared to the drafting of the sheet carried out in the previous year. The annual review of the conservation sheets gives useful information on the importance of constant monitoring, and on the proposal of targeted conservation interventions. SCIMA enables the planning of regular maintenance projects and sets the stage to assess risk and to indicate restoration interventions in areas particularly subject to decay.

\section{Discussion}

The last part of the project aimed toe create a database which would allow an easy compilation of forms, and a better correlation of the data entered. The choice to create SCIMA with closed fields and to exclude the parts of manual compilation, which is too subjective, was dictated by the possibility of implementing a database that could facilitate the management of the data entered. YOCOCU APS aspires to make the SCIMA database an open-source tool to share the data entered, and to lay the foundation for a common mapping of mural artwork. More and more, the digitization of information is a process that, in recent years, has assumed ever greater rates of development. There is no branch of activity that does not provide for a digitization of information processed, even if the operational costs are still high. This involves the growing problems of information management (archiving), indexing, conservation over time and maintenance of data in a recognizable format.

\section{Conclusions}

SCIMA allows technical information from different murals to be centralized and then archived virtually, so that it is constantly updated and shared to a greater number of people. Currently there are thousands of sites dedicated to the dissemination of urban art, but there is not one common lexicon. YOCOCU APS, through SCIMA, aspires to share a tool for describing the technical, technological and morphological characteristics of the degradation of mural artworks. The management of the specific lexicons identified in the field studies and the related photographic documentation lay the foundation for the creation of a glossary that is supported by a shared and defined photographic dictionary. 
Author Contributions: All authors contribute equally. All authors have read and agreed to the published version of the manuscript.

Funding: This research received no external funding.

Acknowledgments: Thanks to all the artists and curators who shared their experiences in this work.

Conflicts of Interest: The authors declare no conflict of interest.

\section{References}

1. Macchia, A.; Rivaroli, L.; Rivaroli, M. Your Art: Yococu Urban ART. In Action/Reaction: Arte Urbana e Street Art a Roma; Palombi Editori: Roma, Italy, 2020; pp. 255-264, ISBN 8860608775.

2. Moore, M. Conservation Documentation and the Implications of Digitisation. J. Conserv. Mus. Stud. 2001, 7, 6-10. [CrossRef]

3. Exp Project. Available online: https://forms.gle/9VYbyW5anRRzyVgs6 (accessed on 10 October 2021).

4. Palermo, L. Beyond the wall: Street art in the fight against the Camorra. Mod. Italy 2017, 22, 381-401. [CrossRef]

5. Santabárbara, C. Street Art Conservation: Beyond Surfaces' Restoration= Conservazione Della Street Art: Oltre il Restauro Delle Superfici; Gangemi Editore: Rome, Italy, 2018; pp. 147-162.

6. Macchia, A.; Rivaroli, L.; Ruffolo, S.A.; La Russa, M.F.; Damiani, F. Protezione Delle opere di Street Art: Materiali e Metodi; Kermes 109-Dossier Street Art: Torino, Italy, 2019; pp. 82-85.

7. Hughes, L. Street Art \& Graffiti Art: Developing an Understanding. Master's Thesis, Georgia State University, Atlanta, GA, USA, 2009.

8. Chatzidakis, M. Street art conservation in Athens: Critical conservation in a time of crisis. Stud. Conserv. 2016, 61, 17-23. [CrossRef]

9. Collina, A. Un "futuro simplece di questo presente imperfetto": Ivan all'Archivio diocesano di Milano. Kermes Restauro Conserv. Tutela Patrim. Cult. 2018, 109, 49-57.

10. Dickens, J.; Rava, A.; Colombini, M.P.; Picollo, M.; Shank, W. Keith Haring in Pisa and Melbourne: Controversy and conservation. Stud. Conserv. 2016, 61, 29-37. [CrossRef]

11. Project Vigo. Cidade de Color. Available online: https:/ / ciudaddecolor.vigo.org/?lang=en (accessed on 10 October 2021).

12. Project GRAArt. Available online: http://www.graart.it/ (accessed on 10 October 2021).

13. Available online: https://github.com/ICCD-MiBACT/Standard-catalografici/tree/master/strumenti-terminologici (accessed on 10 October 2021).

14. Whiteside, A.B. Cataloguing Cultural Objects: New Descriptive Cataloguing Guidelines for the Cultural Heritage Community. Art Doc. J. Art Libr. Soc. N. Am. 2005, 24, 16-18. [CrossRef]

15. Coburn, E.; Lanzi, E.; O’Keefe, E.; Stein, R.; Whiteside, A. The Cataloging Cultural Objects experience: Codifying practice for the cultural heritage community. IFLA J. 2010, 36, 16-29. [CrossRef]

16. Crim, H.; Ferguson, R.; Knight, K. Cataloging Public Art in Lewiston and Auburn. Community Engaged Research Reports, 44. 2017. Available online: http:/ / scarab.bates.edu/community_engaged_research/44 (accessed on 10 October 2021).

17. Available online: https://artsandculture.google.com/partner/inward-osservatorio-sulla-creativit\%C $3 \% \mathrm{~A} 0$-urbana?hl=it (accessed on 10 October 2021).

18. Grupo de Arte Urbano. Anexo I. Propuesta de Código Deontológico Para la Conservación y Restauración de Arte Urbano en Ge-Conservación $\mathrm{n}^{\circ}$ 10. Monográfico Arte Urbano. Conservación y Restauración d Intervenciones Contemporáneas 2016, 10, 188-192. Available online: https://www.ge-iic.com/ojs/index.php/revista/article/view/419. (accessed on 3 November 2021).

19. Delgado, A.L.M. La postura del artista ante los museos de arte urbano en el contexto latinoamericano. Ge-Conservacion 2019, 16, 193-203. [CrossRef]

20. Ciancabilla, L. The Sight Gallery: Salvaguardia e Conservazione Della Pittura Murale Urbana Contemporanea a Bologna; Bolonia University Press: Bologna, Italy, 2015.

21. Cadetti, A. Conservare La Street Art. Le Problematiche Del Muralismo Contemporaneo In Italia; Edifir: Firenze, Italy, 2019.

22. Luque Rodrigo, L.; Moral Ruiz, C. El Arte Urbano Como Patrimonio Inmaterial Posibilidades para su protección y difusión. In Proceedings of the I Simposio Anual de Patrimonio Natural y Cultural ICOMOS España, Valencia, Spain, 1 January 2021; pp. 57-64.

23. Chatzikadis, M. Preventive conservation and monitoring of Street art, graffiti, and public murals: Education and training as an effective tool. In Proceedings of the En Actas VI Congreso Ge-IIC, Madrid, Spain, 16 July 2018; pp. 99-106. Available online: https:/ / www.ge-iic.com/2018/10/03/actas-del-vi-congreso-del-geiic/ (accessed on 30 October 2021).

24. Cordaro, M.; Mazzi, M.C. Censimento Conservativo Dei Beni Artistici e Storici; Guida Alla Compilazione Delle Schede; Quasar: Roma, Italy, 1993.

25. Di Cosimo, F.; Giovannone, C.; Guglielmi, A.; Longo, C.; Prisco, G. La scheda conservativa di rilevamento per dipinti murali staccati. In Filologia dei Materiali e Trasmissione al Futuro: Indagini e Schedatura sui Dipinti Murali del Museo Archeologico Nazionale di Napoli; Prisco, G., Ed.; Gangemi Editore SPA: Roma, Italy, 2011.

26. Marcone, A.M.; Paris, M.; Buzzanca, G.; Lucarelli, G.; Gerardi, G.; Giovagnoli, A.; Ivone, A.; Nugari, M.P. Il progetto ICR di manutenzione e controllo della Galleria Doria Pamphilj: Schedatura conservativa e monitoraggio ambientale. Bollettino ICR 2001, $2,44-67$. 
27. Olivetti, C. Proposta di una scheda per la raccolta dei dati nel restauro dei dipinti su tela. Quad. Degli Ist. Cult. Della Prov. Viterbo 1988, 1, 25-159.

28. Úbeda García, M. Propuesta de un Modelo De Registro Para El Análisis Y Documentación De Obra De Arte Urbano. GeConservación 2016, 169-179. Available online: https://ge-iic.com/ojs/index.php/revista/article/view/410 (accessed on 30 October 2021). [CrossRef]

29. Rella, L. Schede Tecniche Per il Restauratore di Dipinti Murali, su Tela e Su Tavola, [Con CD-ROM]; Hoepli Editore: Milano, Italy, 2009.

30. Haddad, N.A.; Fakhoury, L.A.; Sakr, Y.M. A Critical anthology of international charters, conventions \& principles on documentation of cultural heritage for conservation, monitoring \& management. Mediterr. Archaeol. Archaeom. 2021, 21, $291-310$.

31. Veillon, R. UNESCO World Heritage Centre-State of Conservation of World Heritage Properties: A Statistical Analysis (1979-2013); Unesco World Heritage Centre: Paris, France, 2014.

32. Ashrafi, B.; Kloos, M.; Neugebauer, C. Heritage Impact Assessment, beyond an Assessment Tool: A comparative analysis of urban development impact on visual integrity in four UNESCO World Heritage Properties. J. Cult. Herit. 2021, 47, $199-207$. [CrossRef]

33. Available online: http://www.icom-cc.org/242/about/terminology-for-conservation/\#.YS1Jpo4zZPY (accessed on 30 October 2021).

34. Available online: http:/ / www.ewaglos.eu/ (accessed on 30 October 2021).

35. Santana Quintero, M.; Blake, B.; Eppich, R.; Ouimet, C. Heritage documentation for conservation: Partnership in learning. The spirit of place. In Proceedings of the Scientific Symposium of ICOMOS, Quebec, QC, Canada, 29 September-4 October 2008.

36. Available online: https://www.getty.edu/research/tools/vocabularies/ (accessed on 3 November 2021).

37. UNI 11182:2006 Beni Culturali-Materiali Lapidei Naturali ed Artificiali-Descrizione Della Forma di Alterazione-Termini e Definizioni ICS, [01.020] [91.100.15]. Available online: http:/ / store.uni.com/catalogo/uni-11182-2006 (accessed on 3 November 2021).

38. Moraitou, E.; Kavakli, E. Knowledge Management Using Ontology on the Domain of Artworks Conservation. In Digital Cultural Heritage; Springer: Cham, Switzerland, 2018; pp. 50-62. [CrossRef]

39. Brajer, I. The problem of vandalism on contemporary outdoor murals and street art. CeROArt 2018. [CrossRef]

40. Ciancabilla, L.; Tusini, G.L. (Eds.) Oltre il Grigio: Conservare, Musealizzare e Restaurare L'arte Urbana Fra Tradizione E Memoria: Atti Della Giornata di Studi del 31 Maggio 2018; Bononia University Press: Bologna, Italy, 2019.

41. García Gayo, E. 2015:“Introducción”. Mural Street Art Conservation. Observatorio del Arte Urbano n 1. pp. 4-5. Available online: https:/ / issuu.com/observatoriodearteurbano/docs/mural__1 (accessed on 30 October 2021).

42. Macchia, A.; Ruffolo, S.A.; Rivaroli, L.; Malagodi, M.; Licchelli, M.; Rovella, N.; Randazzo, L.; La Russa, M.F. Comparative study of protective coatings for the conservation of Urban Art. J. Cult. Herit. 2020, 41, 232-237. [CrossRef]

43. García Gayo, E. Etapas del Arte Urbano. Aportaciones para un Protocolo de conservación. Ge-Conservación Conservação 2016, 10, 97-108. Available online: https://www.ge-iic.com/ojs/index.php/revista/article/view/401/pdf (accessed on 30 October 2021). [CrossRef]

44. Mangini, F.; D'Alvia, L.; Del Muto, M.; Dinia, L.; Federici, E.; Palermo, E.; Del Prete, Z.; Frezza, F. Tag recognition: A new methodology for the structural monitoring of cultural heritage. Measurement 2018, 127, 308-313. [CrossRef]

45. Macchia, A.; Mangini, F.; Ruffolo, S.A.; Muzi, M.; Rivaroli, L.; Ricca, M.; La Russa, M.F.; Frezza, F. A novel model to detect the content of inorganic nanoparticles in coatings used for stone protection. Prog. Org. Coat. 2016, 106, 177-185. [CrossRef]

46. Mangini, F.; Dinia, L.; Del Muto, M.; Federici, E.; Rivaroli, L.; Frezza, F. Study of optical tag profile of the tag recognition measurement system in cultural heritage. J. Cult. Herit. 2020, 45, 240-248. [CrossRef]

47. Prego, C. El Museo Urbano Fija a Vigo en el Mapa del 'Street Art' en Faro de Vigo, 30 de Dicembre. 2018. Available online: https:/ / www.farodevigo.es/gran-vigo/2018/12/30/museo-urbano-fija-vigo-mapa/2025294.html (accessed on 30 October 2021). 